\title{
Propagation from root cuttings for black locust (Robinia pseudoacacia L.) improvement in Hungary: a review
}

\author{
Rédei, K. ${ }^{1}$, Rásó, J. ${ }^{2}$, Kiss, T. ${ }^{2}$ \& Keserü, Zs. ${ }^{2}$ \\ ${ }^{1}$ Faculty of Agricultural and Food Sciences and Environmental Management, University of Debrecen, Debrecen, Hungary \\ ${ }^{2}$ Forest Research Institute, National Agricultural Research and Innovation Centre, Püspökladány, Hungary \\ Author for correspondence: keseruzs@erti.hu
}

\begin{abstract}
Summary: Black locust (Robinia pseudoacacia L.) is a valuable stand-forming tree species introduced to Europe approximately 400 years ago from North America. Today it is widely planted throughout the world, first of all for wood production. In Hungary, where black locust has great importance in the forest management, it is mainly propagated by seeds. But since the seed-raised plants present a great genetic variation, this type of propagation can not be used for Robinia's improved cultivars. In the Hungarian black locust clonal forestry, propagation from root cuttings can be used for reproduction of superior individuals or cultivars in large quantities. However, this method demands more care than raising seedlings from seeds and can be applied with success in well-equipped nurseries.
\end{abstract}

Rédei, K., Rásó, J., Kiss, T. Keserü, Zs. (2019): Propagation from root cuttings for black locust (Robinia pseudoacacia L.) improvement in Hungary: a review. International Journal of Horticultural Science 25(1-2): 39-41. https://doi.org/10.31421/IJHS/25/1$2 . / 2384$

Key words: black locust, clonal, forestry, Robinia pseudoacacia L., root cuttings, vegetative propagation

\section{Introduction}

Black locust produces valuable water-and rot-resistant timber and firewood, and provides nectar for making highquality honey. In Hungary, it provides $25 \%$ of all timber and around 25000 tons of honey a year, this represents $40-50 \%$ of all Robinia honey production in Europe. It can also be used to control soil erosion and improve damaged sites; it is able to tolerate both toxic and extremely dry soils and can rapidly take over mining areas, abandoned farmland and fire-damaged sites, as it thrives during early stages of forest regeneration. The tree's tolerance of poor-quality land also makes it popular in cities as an ornamental plant (Keresztesi, 1988; Rédei, 2013).

Black locust's fast growth and stress tolerance are important characteristics for relatively short rotation cycle silviculture. Because of its many desirable attributes, the species is admirably suited to utilization in north temperate areas of the world (Hannover, 1990). Black locust trees show considerable variability in stem and branching form, timber production, wood quality, and stress tolerance. From this point of view rapid propagation of selected superior trees is important for mass production of plants, with desirable genetic traits (Chalupa, 1992).

R. Fleischman, the famous Hungarian plant breeder, began breeding black locust in 1930. Unfortunately, his promising trials perished during the Second World War. After the War, the demand of large scale agricultural farms for wood decreased. At the same time, the timber industry could convert only a small part of black locust wood into modern products because of its poor quality. This was the reason priority given for breeding this species and efforts were made to improve wood quality (Keresztesi, 1988).

In Hungary a new black locust breeding and improvement program was started early in the 1960's. In the course of selection breeding, existing black locust stands were considered to be separate provenances, and the best stands, as well as individual plus trees were identified. Plus trees were multiplied up to produce cultivars, the most promising of which were then planted out under a variety of conditions. Many of the best cultivars have proved to be quite site-specific, and some require particular propagation and growing techniques. There is a need to improve specific establishment, tending and harvesting techniques tailored to meet the needs of particular cultivars (Keresztesi, 1988).

\section{Vegetative propagation methods for forest tree species}

The majority of main forest species possess the ability to reproduce the whole organism from a single organ, tissue or sometimes from a cell. The vegetative reproduction of forest trees may be solved by autovegetative or heterovegetative propagation. Autovegetative propagation develop all necessary organs by themselves, while heterovegetative propagation mean that a port of the vegetative apparatus originates from another plant, such as the various forms of grafting (Mátyás, 1983).

Stem cuttings, in which a piece of stem is part buried in the soil, including at least one leaf node. The cutting is able to produce new roots, usually at the node. Root cuttings, in which a section of root is buried just below the soil surface, and produces new shoots. Scion cuttings are used in grafting. Leaf cuttings, in which a leaf is placed on moist soil. These have to develop both new stems and new roots. Some leaves will produce one plant at the base of the leaf. In some species, multiple new plants can be produced at many places on one leaf, and these can be induced by cutting the leaf veins (Mátyás, 1983). 
Although some species, such as willow, grown simply by placing a cutting into moist ground, the majority of species require more attention. Most species require humid, warm, partially shaded conditions to strike, thus requiring the approach above to be followed. Particularly difficult species may need cool air above and warm soil. In addition, with many more difficult cuttings, one should use the type of cutting that has the most chance of success with that particular plant species (Mátyás, 1983).

The primary requirement for reproducing black locust cultivars was to develop a reliable vegetative propagation method which ensures their profitable production in forestry nurseries functioning under variable circumstances. According to the practice oriented innovative results obtained up till now, propagation from root cuttings seems to be the most suitable method for black locust plantation (clonal) forestry (Keresztesi, 1988; Bujtás, 1992; Rédei, 2013).

\section{Black locust cultivars propagation from root cuttings}

The primary requirement for reproducing black locust clones and cultivars was to develop reliable vegetative methods. A working group in the Hungarian Forest Research Institute developed a method for a large-scale production of black locust plants from root cuttings, based on the vital sprouting ability of the roots of this species (Keresztesi, 1988). This technique has several advantages:

- large numbers of new plants can be generated from each parent plant,

- the plants derived from root cuttings are relatively large and vigorous,

- plants from root cuttings are free of foliar pests and pathogens that might affect their parents, such as stem and leaf nematodes.

For this propagation method, root pieces cut into $8-10 \mathrm{~cm}$, or chopped to $3-5 \mathrm{~cm}$ in length, are used (Figure 1). Root cuttings are most effective if taken when plants are dormant, usually between November and February/March. This timing maximizes the stored energy in the roots and minimizes the stress on the parent plant. Once a plant breaks bud in the spring, energy begins to move out of the roots and into the plant, reducing the effectiveness of root cuttings.

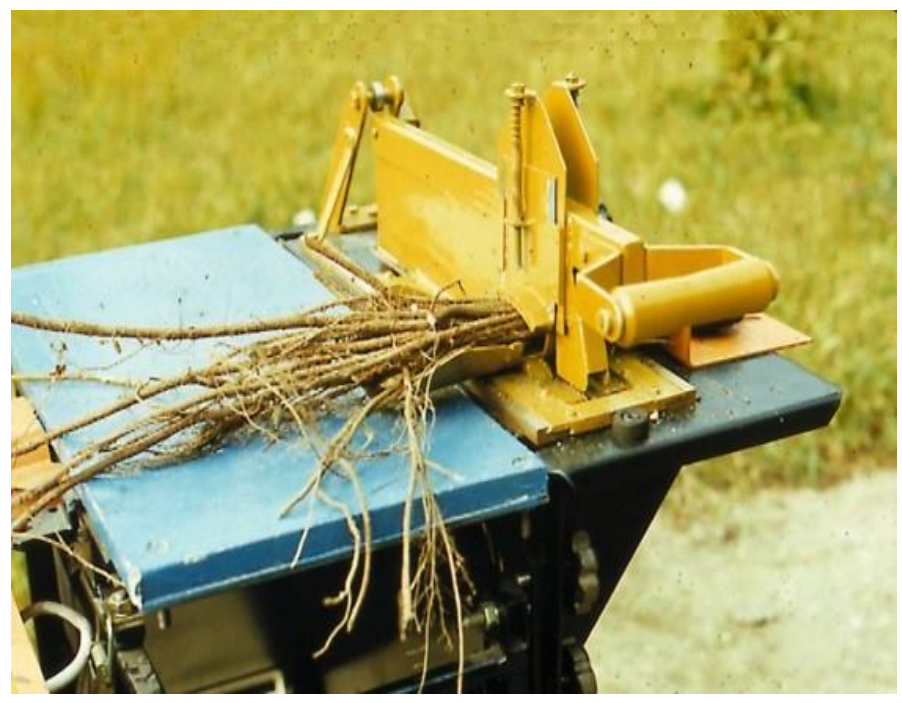

Figure 1. Black locust root cuttings
When plants are silted after planting with a quantity of water corresponding to $10 \mathrm{~mm}$ precipitation or more, care is taken so the upper end of the cuttings remain under the soil surface; otherwise they might dry up. At the same time, the cuttings must not be covered with a soil layer greater than $1 \mathrm{~cm}$. Twenty-five to 20 root pieces are sown per running meter. The thickness of soil core should be uniform and not exceed $4 \mathrm{~cm}$. Root pieces for further propagation can be collected from the plants we raised the first year (Bujtás, 1992). In the case of manual inserting of the rootcuttings into ground, according to experiments, 10-15 plants can be raised per running meter. In general, seedling are lifted in spring and that is the time when roots for propagation are collected. Normally this takes some 5 to 6 weeks. The average height of the one-year old plants is 1.2-1.5 m (Bujtás, 1992).

\section{Black locust cultivar trial: a case study}

The trial was established in the forest subcompartment Szentkirály 47H (Central-Hungary, Danube-Tisza Interfluves). The subcompartment presents slightly wavy surface, humus sandy soil without ground-water influence. The R.p. cv. 'Üllö $i$ ' planting material was selected from 1 year old rooted cuttings and the common black locust planting material was 1 year old selected seedlings.

The following parameters were measured at age of 20 years: stem number, diameter at breast height and tree height. The calculated parameters were the followings: basal area, stem volume, volume of dead trees, stand volume (living stock) and mean tree volume. The stem volume $\left(\mathrm{v}_{\mathrm{st}}\right)$ was calculated using the volume function based on the volume table for black locust (Kolozs \& Sopp, 2000):

$$
\mathrm{V}_{\mathrm{st}}=\frac{d^{2} * h^{p 0+1}}{(h-1.3)^{p 0} * 10^{8}} *\left(p_{1} * d * h+p_{2} * d+p_{3} * h+p_{4}\right),
$$

where $d$ is $d . b . h .(\mathrm{cm}), h$ is tree height $(\mathrm{m}), p o=4$,

$$
p_{1}=-0.6326, p_{2}=20.23, p_{3}=0.00 \text { and } p_{4}=3,034 \text {. }
$$

The stand volume (living stock) (V) has been determined by means of the program developed by the Hungarian Forest Research Institute (HFRI) for expressing the wood volume; the mean tree volume (v) is computed according to the relation: $v=$ $V N^{-1}$, where, $N=$ stem number per hectare (Table 1). The stem form classes used by us are as follows: $\mathrm{x}_{1}$ ) Straight, cylindrical, healthy stems, reaching to the top of the crown; $x_{2}$ ) The stem is straight, forks are tolerated, but only if they are in the uppermost third of the tree; $\mathrm{x}_{3}$ ) The stem is crooked and leaning; $\mathrm{x}_{4}$ ) Very crooked in more than one dimension, low branching, forked trees with stem defects, broken crown or stem rot. The average stem form value (SFV) was determined on base of the following formula:

$$
\mathrm{SFV}=\frac{x_{1} n_{1}+x_{2} n_{2}+x_{3} n_{3}+x_{4} n_{4}}{n_{1}+n_{2}+n_{3}+n_{4}}
$$

where $x_{1}, x_{2}, x_{3}, x_{4}=$ stem form classes, $n_{1}, n_{2}, n_{3}, n_{4}=$ tree numbers belonging to the single tree quality classes.

A comparison of basal area and mean tree volume illustrated that the cultivar R.p. 'Üllöi' reached higher value than the control black locust (Figure 2). In mean tree volume the difference is $19.7 \%$. By growing selected black locust cultivars, it is possible to increase the ratio of wood material using for industrial purposes (in our case study by $32 \%$ ). 
Table 1. Stand structure and quality parameters of the experimental plots

\begin{tabular}{|c|c|c|c|c|c|c|c|}
\hline $\begin{array}{c}\text { Age } \\
\text { Year }\end{array}$ & $\begin{array}{c}\text { Stem } \\
(\text { number/ } \\
\text { ha) }\end{array}$ & $\begin{array}{c}\text { Mean } \\
\text { height } \\
(\mathbf{m})\end{array}$ & $\begin{array}{c}\text { Mean } \\
\text { DBH } \\
(\mathbf{c m})\end{array}$ & $\begin{array}{c}\text { Basal } \\
\text { area } \\
\left(\mathbf{m}^{\mathbf{2}} / \mathbf{h a}\right)\end{array}$ & $\begin{array}{c}\text { Volume } \\
\left(\mathbf{m}^{\mathbf{3}} / \mathbf{h a}\right)\end{array}$ & $\begin{array}{c}\text { Mean } \\
\text { tree } \\
\text { volume } \\
\left(\mathbf{m}^{\mathbf{3}}\right)\end{array}$ & $\begin{array}{c}\text { Stand- } \\
\text { value } \\
\mathbf{i n d e x} \\
\mathbf{( S F V})\end{array}$ \\
\hline \multicolumn{7}{|c|}{ R.p. cv. 'Üllöi' } \\
\hline 20 & 1220 & 17.6 & 15.5 & 23.0 & 218.3 & 0.188 & 1.65 \\
\hline 20 & 1180 & 17.2 & 14.4 & 19.1 & 178.7 & 0.151 & 2.41 \\
\hline
\end{tabular}

\section{Conclusions}

Experiments with black locust have shown that it is a tree species with great regenerative potential from root cuttings. This method can be used effectively for black locust selection programmes. Therefore, its application is recommended for meeting the qualitative requirements of propagation material as well. The paper also confirmed that by establishing black locust cultivar plantations, the quality of wood material can be increased to a large extent.

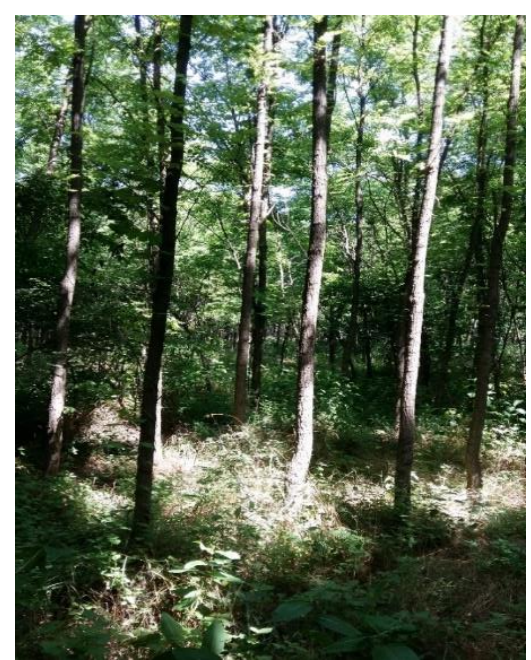

Figure 2. R.p. 'Üllöi’ cultivar plantation at Szentkirály

\section{Acknowledgements}

The research on black locust improvement in Hungary has been partly supported by GINOP (project number: 2.1.2-8-1-416-2017-00022).

\section{References}

Chalupa, V. (1992): Tissue Culture Propagation of Black Locust. In: Proceedings: International Conference on Black Locust: Biology, Culture and Utilization. Michigan State University, East Lansing, MI: 115-125.

Hanover, J. W. (1990): Physiological genetics of black locust (Robinia pseudoacacia L.): A model multipurpose tree species. In: Werner, D., Muller, P. (Eds.), Fast growing trees and nitrogen fixing trees. International Conference, Marburg, October 8th-12th, 1989. Gustav Fischer Verlag, Stuttgart-New York: 175-183.

Keresztesi, B. (1988): The Black Locust (edit). Budapest. Academic Publishing House. 196.

Kolozs, L., Sopp, L. (2000): Wood Volume Tables. State Forest Service. Ed. Budapest. 271.

Mátyás, Cs. (1983): An Introduction to Forest Tree Improvement. University Multipliers. Sopron. 175.

Osváth-Bujtás, Z. (1992): Seed and Root Propagation of Black Locust. In Proceedings: International Conference on Black Locust: Biology, Culture and Utilization. Michigan State University. East Lansing. MI: 49-53.

Rédei, K., Osváth-Bujtás, Z., Balla, I. (2002): Clonal approaches to growing black locust (Robinia pseudoacacia) in Hungary: a review. Forestry 75(5): 547-552.

Rédei, K. edit. (2013): Black Locust (Robinia pseudoacacia L.) Growing in Hungary. Hungarian Forest Research Institute. Budapest. 77. 